\title{
The Effect of Business Risk and Firm Size on Firm Value with Debt Policy as Intervening Variable
}

\author{
Akhmad Bandanuji ${ }^{\bowtie}$, Moh. Khoiruddin \\ Management Department, Faculty of Economics, Universitas Negeri Semarang, Semarang, Indonesia
}

\section{Article Information}

Article History:

Received January 2020

Approved February 2020

Published June 2020

Keywords:

Business Risk, Firm Size,

Debt Policy, Firm Value.

\begin{abstract}
This study aims to determine the effect of business risk and firm size on firm value with debt policy as intervening variable. The population used in this study are property and real estate companies listed on Indonesia Stock Exchange (BEI) during 2014-2018. Sample determination was done by purposive sampling method. Methods of data analysis using multiple linear regression analysis and path analysis. The results showed that business risk negatively affect the debt policy, while firm size has a positive effect on debt policy. Business risk negatively affects firm values while firm size and debt policy have a positive effect on firm value. Debt policy is only able to mediate the impact of business risk on corporate value.
\end{abstract}

\section{INTRODUCTION}

Generally a company will always try to achieve its goals, both short-term goals such as maximizing corporate profits with resources owned and long-term goals such as being able to increase firm value and the welfare of shareholders (Suwardika \& Mustanda, 2017). Companies go public tend to always increase the value of the company to attract the attention of investors (Pramana \& Mustanda, 2016).

Firm value is selling price oh the company when the company is sold. Firm value of companies that go public in the capital market can be seen from the price of their shares. High and low stock prices reflect the high and low values of the company (Wiagustini, 2013). The welfare of shareholders can be used as a description of the value of the company, firm value of the company shows how well the company's performance (Sari \& Wirajaya, 2017).

Firm value can be seen from the market price of its shares. Where the higher the share pri- ce, the value of the company and the prosperity of the shareholders also increases. Firm value can also be shown from the amount of Price Book Value (PBV) which is a comparison between the share price and the book value per share (Subramanyam \& Wild, 2010). PBV ratio that has a value of more than 1 (one) means that manufacturing companies are considered to have good performance because investors are willing to buy shares more expensive than the book value.

Funding decisions are very important for companies to carry out operational activities, when a company is built, the company will need optimal capital. Companies can choose various funding alternatives that will later be considered to maximize the value of the company (Haruman, 2008). The debt policy is included in the company's funding decisions that are sourced externally. Some companies consider that using debt is safer than issuing new shares. The use of debt to finance company activities can provide benefits derived from tax deductions because of the interest paid due to debt will reduce taxable income (Mulianti, 2010). 
Angga and Wiksuana (2016), Rai and Mertha (2016), Saraswati et al. (2016), and Sari and Wirajaya (2017) found that debt policy had a significant positive effect on firm value. The opposite results obtained by Mahendra et al. (2012), Hartono et al. (2013), Ogolmagai (2013), and Kodongo et al. (2014) which proves that debt policy has a negative and significant effect on firm value.

In line with the increase in value, the company is faced with the emergence of business risk. Joni and Lina (2010) revealed that business risk is one of the risks faced by companies when running their operations. According to Brigham and Houston (2013), business risk is uncertainty regarding the projected return on assets in the future. The value of companies that have high business risks because of the funding decisions they choose, will fall in the eyes of investors when there is a risk of bankruptcy.

Research by Yuliani et al. (2013) as well as Saraswati et al. (2016) shows that business risk has a positive effect on firm value. Whereas Wigaustini and Pertamawati (2015) and Sari and Wirajaya (2016) show that business risk has a negative effect on firm value.

Every decision to be taken by a company must consider the business risks faced, including the decision in determining the debt policy (Sari \& Wirajaya, 2017). Alnajjar (2015) states that when companies face higher business risks, they will tend to avoid debt to minimize risks related to difficulties in fulfilling their obligations in the future.

Research by Joni and Lina (2010), Wimelda and Marlinah (2013), and Wiagustini and Pertamawati (2015), found that business risk has a positive effect on debt policy. While Psillaki (2009), Mulianti (2010), and Sari and Wirajaya (2017) concluded that business risk has a negative effect on debt policy.

Another factor that is predicted to affect the value of the company is firm size. Companies that have a large total assets show that the company has reached the stage of maturity, which at this stage the cash flow is positive and is considered to have good prospects in a relatively long period of time, while also reflecting that the company is relatively more stable and more capable of producing profit compared to companies with small total assets (Suwardika \& Mustanda, 2017). This will be positively responded by investors and make the company's stock price increase so that it will increase the firm value.

Research on Rasyid et al. (2015), Wiagustini and Pertamawati (2015), and Angga and Wiksuana (2016) shows that firm size has a positive effect on firm value. However, Rai and Mer- tha (2016) illustrate that firm size has a negative influence on firm value.

Riyanto (2001) states that the firm size also affects the company's capital structure. The firm size can affect the capital structure because the larger a company will tend to use a larger debt. Because one of the advantages of a large-sized company is likely to be more trusted by creditors because it is considered to have a smaller risk compared to companies that have a small company size.

Salehi (2012), Alnajjar (2015), and Wiagustini and Pertamawati (2015) show that firm size has a positive effect on debt policy. While Khalid (2011) and Damayanti (2013) show that firm size has a negative effect on debt policy.

The diversity of the results of previous studies shows that there are research gaps, therefore re-research related to business risk, firm size and debt policy on firm value needs be done to strengthen the results to previous studies.

This study uses debt policy as an intervening variable because debt is a very sensitive instrument. The manager in determining the debt policy must consider the condition of the company related to the business risks faced and how big the company is because the debt policy taken will affect firm value.

The objects used in this study are property and real estate companies listed on the Indonesia Stock Exchange in 2014-2018. The property and real estate business is a very lucrative business. The large population of Indonesia requires housing that must be met. This is a very good business opportunity, therefore the property and real estate business is highly developed in Indonesia.

Based on the above thinking, then there is a research gap from some of the results of previous studies regarding the effect of business risk, company size and debt policy on company value, the authors are interested in conducting research with the aim to determine the effect of business risk and company size on firm value through debt policy as an intervening variable on property and real estate companies listed on the Indonesia Stock Exchange in 2014-2018.

\section{Hypothesis Development}

Business risk is one of the important indicators for companies in determining the company's funding system, especially in the decision to use debt (Sari \& Wirajaya, 2017). In accordance with the trade off theory which states that the use of debt that is too high will increase the risk of bankruptcy. Harjanti and Tandelilin (2007) argue that a company's business risk can be described by 
measuring fluctuations in company profits. Companies that experience earnings fluctuations face an uncertain ability to collect funds to repay loans to creditors. Therefore companies that have high business risks must be more careful in determining their debt policies.

Mulianti (2010) and Sari and Wirajaya (2017) conclude that business risk has a significant negative effect on debt policy. Based on this, the following hypothesis can be arranged:

$\mathrm{H} 1$ : Business risk has a negative effect on debt policy.

Firm size describes the size of a company. According to Putri (2012) large-sized companies have large operational activities, thus requiring greater funds compared to smaller-sized companies.

In addition, large companies also have higher taxable income than small companies. Signaling theory shows that the greater the size of the company, the more transparent the company is in disclosing the company's performance to outsiders, thus the company is easier to get loans because it is increasingly trusted by creditors.

Alnajjar (2015) and Wiagustini and Pertamawati (2015) show that firm size has a significant positive effect on debt policy. Based on this, the following hypotheses can be arranged:

$\mathrm{H} 2$ : The firm size has a positive effect on debt policy.

Joni and Lina (2010) state that a company is considered to face a high business risk if it produces profits that fluctuate between one period and another. Harjanti and Tendelilin (2007) stated that the higher business risk faced by the company, indicated that the company was not in a stable condition because it was unable to maintain profit levels so that it could potentially fail to fulfill its obligations which then increased the risk of bankruptcy. As a result, investors are reluctant to invest their capital so that stock market prices fall which then reduces the value of the company.

Wiagustini and Pertamawati (2015), and Sari and Wirajaya (2017) studies show that business risk has a negative effect on firm value. Based on this, the following hypothesis can be arranged: $\mathrm{H} 3$ : Business risk has a negative effect on firm value.

According to Suwardika and Mustanda (2017) large-sized companies have reached the maturity stage, which at this stage the cash flow has been positive and is considered to have good prospects in a relatively long period of time, while also reflecting stability and more ability to generate profits. Investors capture this as a positive signal related to the company's ability to provide a greater rate of return so that it will increase stock prices which then increase the firm value.

Research by John and Amarjit (2012), Rasyid et al., (2015) and Pratama and Wiksuana (2016) show that firm size has a positive effect on firm value. Based on this, the following hypotheses can be arranged:

H4: Firm size has a positive effect on firm value.

The debt policy adopted by the company will increase the company's ability to carry out its operations. Sari and Wirajaya (2017) stated that the higher the debt policy adopted by the company, investors assume that the company has many opportunities to use its capital for expansion to develop its business. So that it will increase company profits while increasing company value

Modigliani-Miller theory states that companies with debt will provide benefits because debt interest can reduce taxable profits, so that the tax paid by the company becomes smaller (tax deductible). Thus, the greater the company's debt, the higher its value and share price (Brigham \& Houston, 2006).

Rai and Mertha (2016) and Sari and Wirajaya (2017) found that debt policy positively influences firm value. Based on this, the following hypotheses can be arranged:

H5: Debt policy has a positive effect on firm value.

Conceptually the company represents a number of risks inherent in its operations, this risk is a business risk, namely how risky the company's stock if the company does not use debt (Brigham \& Houston, 2013). Business risk can increase when companies use high debt to meet their funding needs. Risks arise along with the emergence of the burden of costs on loans made by the company. The greater the burden of costs to be borne, the greater the risk faced by the company. This will also increase the possibility of bankruptcy (Harjanti \& Tendelilin, 2007).

Investors will assume that when a company faces an increasing risk of bankruptcy due to the high burden of debt costs, the company will sell its assets to pay off debt, not to return the value of the shares invested by investors. As a result, investors will not be interested in investing their capital in the companies concerned so that the stock market price drops which then results in lowering the firm value. 
Research conducted by Wiagustini and Pertamawati (2015) succeeded in proving that business risk influences company value through debt policy. So it is predicted that debt policy can mediate the effect of business risk on firm value. Based on this, the following hypotheses can be arranged: H6: Business risk influences firm value through debt policy.

Large companies have large operational activities, so they need more funds (Putri, 2012). Large companies more easily obtain loans because the value of assets that are used as collateral is greater so that the level of creditor confidence such as banks or financial institutions is also large (Suwardika \& Mustanda, 2017). So large companies tend to have high debt policies.

Companies that raise their debts are seen as companies that are confident in their future prospects because they have many opportunities to use their capital for expansion to develop their business. So that it will increase company profits while increasing firm value (Anggraini, 2015).

Rai and Merta (2016) state that corporate value can be created with a debt policy, where the debt policy also depends on the firm size. Therefore, there is relevance between the firm size with the debt policy and the firm value.

Hermuningsih (2012) shows that firm size has an indirect effect on firm value with debt policy as an intervening variable. Based on this, the following hypotheses can be arranged:

H7: The firm size affects the firm value through debt policy.

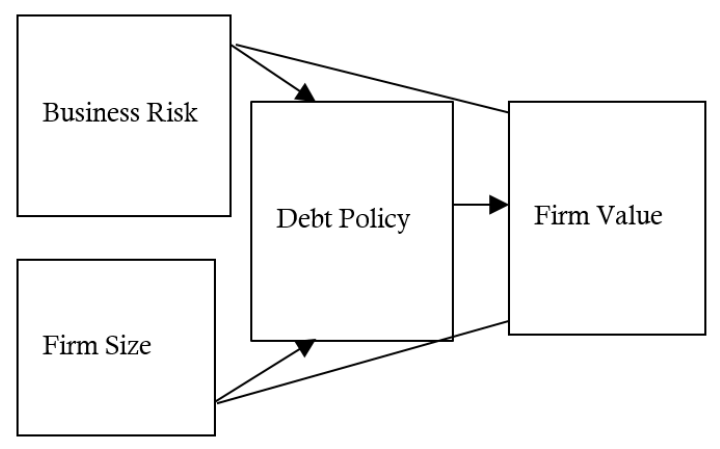

Figure 1. Research Model

\section{METHOD}

\section{Types of Research}

Judging from the objectives to be achieved, this research is included in the type of quantitative research. The data used in this study are secondary data sourced from the company's financial statements published on the IDX.
Population, Samples, and Sampling Techniques

The population in this study is the financial statements of property and real estate companies listed on the Indonesia Stock Exchange in 2014-2018 as many as 52 companies. Sampling was done using a purposive sampling method and produced a sample of 27 companies.

\section{Research Variable}

This study uses firm value (PBV) as the dependent variable. While the independent variables are business risk (BRISK), firm size (SIZE), and debt policy (DER). Aside from being independent variable, the debt policy (DER) in this study is also used as an intervening variable.

\section{Operational Definition and Variable Measurement}

Firm value is an investor's perception of the company's success rate which is often associated with stock prices (Erfiana \& Anindya, 2016). Where the higher the share price, the firm value and the prosperity of the shareholders also increases (Sari \& Wirajaya, 2017). Firm value is proxied by price book value (PBV). PBV is the result of a comparison between the stock price and the book value of shares. Price book value (PBV) can be formulated as follows according to Kusumajaya (2011).

$$
\mathrm{PBV}=\frac{\text { Market Price per Share }}{\text { Book Price per Share }}
$$

Business risk is the risk level of a company's operations if it does not use debt. A company is considered to face business risk if it produces profits that fluctuate between one period and another (Joni \& Lina, 2010). In this study, business risk is calculated using the natural log formula from the standard deviation of EBIT where similar things have been done by previous researchers such as Chen and Jiang (2001), Harjanti and Tendelilin (2007) and Furaida (2010).

$$
\mathrm{BRISK}=\operatorname{Ln}(\sigma \mathrm{EBIT})
$$

The firm size describes the size of a company that can be expressed by total assets (Ridloah, 2010). According to Wiagustini and Pertamawati (2015), a proxy that can be used to describe the size of a company is the narutal logarithm of total assets.

$$
\mathrm{SIZE}=\mathrm{Ln} \text { (Total Aset) }
$$


Debt policy is a company funding policy sourced externally taken by management in order to obtain a source of funding for the company so that it can be used to finance the company's operational activities (Maftukhah, 2013). The formula used to measure debt policy in this study is DER (Debt Equity Ratio), which is a ratio that compares total debt with own capital (Naini \& Wahidahwati, 2014).

$$
\text { DER }=\frac{\text { Total Amount of debt }}{\text { Total Capital }}
$$

\section{Data Analysis Method}

This research uses descriptive analysis method to provide an overview of research variable data that can be seen from the minimum, maximum, mean and standard deviation values. In addition, a classic assumption test is also performed, then multiple linear regression analysis using SPSS 25, then developed with path analysis for intervening variable (Ghozali, 2011).

Regression analysis in this study used two sub-structures. Structure 1 is a regression analysis of mediation variables and sub-structure 2 is a regression analysis of the dependent variable. The regression equation 1 and 2 models in this research are as follows:

$\begin{array}{ll}\text { DER: } \alpha+\beta 1 \text { BRISKit }+\beta 2 \text { SIZEit }+\varepsilon 1 \\ \text { PBV: } \alpha+\beta 1 \text { BRISKit }+\beta 2 \text { SIZEit }+ \\ \text { 33DERit }+\varepsilon 2 \\ \text { Information: } & \\ \text { PBV } & : \text { Firm Value } \\ \text { DER } & : \text { Debt Policy } \\ \text { BRISK } & : \text { Business Risk } \\ \text { SIZE } & : \text { Firm Size } \\ \varepsilon & : \text { error }\end{array}$

\section{RESULT AND DISCUSSION}

\section{Descriptive Analysis}

Business Risk (BRISK) is a natural logarithm of the standard deviation of earnings before interest and tax (EBIT). Table 1 shows the BRISK mean of 25.1121. The maximum value of BRISK is 29.91, namely at PT Bekasi Asri Pemula Tbk in 2016 and the minimum value of BRISK is 20.11 , namely PT Metropolitan Kentjana Tbk in 2016. The standard deviation value of BRISK is 2.18029 which means the tendency of BRISK data between one company and other companies during the period has a level deviation of 2.18029 .

Firm size (SIZE) is the natural logarithm of the company's total assets. In Table 1 shows the mean value of SIZE of 28.8242. The maximum value of SIZE is 31.97 , namely at PT Jaya Konstruksi Tbk in 2014 and the minimum value of SIZE is 24.45 , namely at PT Wijaya Karya (Persero) Tbk in 2017. The standard deviation value of SIZE is 2.02021 which means the tendency of SIZE data between one company and other companies during the period This has a deviation rate of 2.02021 .

The debt policy as measured by the debt to equity ratio (DER) is the ratio of total liabilities to total equity. It can be seen in Table 1 that the mean DER value is 1.0855 . While the maximum value of DER is 3.77, that is at PT Metropolitan Kentjana Tbk in 2016 and the minimum value of DER is 0.04 , namely at PT Greenwood Sejahtera Tbk in 2018. The standard deviation value of DER is 0.87820 which means the tendency of DER data between one company and another company during that period the rate of deviation was 0.87820 .

Firm value measured by price book value (PBV) is the ratio of price per share to book value per share. It can be seen in Table 1 that the mean value of $\mathrm{PBV}$ is 1.7139 and the PBV standard deviation value is 2.09295 where the standard deviation value is smaller than the average value and the maximum value. This condition shows the tendency of PBV data between one company and another company during that period has a deviation level of 2,09295. The maximum PBV value of 9.85 is at PT Plaza Indonesia Reality Tbk in 2017 and the minimum PBV value of 0.09 is at PT Wijaya Karya (Persero) Tbk in 2018.

Table 1. Descriptive Statistical Test

\begin{tabular}{llllll}
\hline & N & Minimum & Maximum & Mean & Std. Deviation \\
\hline PBV & 135 & 0.09 & 9.85 & 1.7139 & 2.09295 \\
BRISK & 135 & 20.11 & 29.91 & 25.1121 & 2.18029 \\
SIZE & 135 & 24.45 & 31.97 & 28.8242 & 2.02021 \\
DER & 135 & 0.04 & 3.77 & 1.0855 & 0.87820 \\
Valid N (listwise) & 135 & & & & \\
Source: Data processed by SPSS 25 (2020) & & & &
\end{tabular}




\section{Classic Assumption Test}

The model in this study has passed the classical assumption test, which is based on the Kolmogorov-smirnov test Asymp value $>$ sig a 0.05 , which means the model is normally distributed. In the multicollinearity test, tolerance values for all variables $>0.10$ and VIF values for all variables $<10$ means that the model is free from multicollinearity. Heteroscedasticity test using Glejser test proves that there are no statistically significant independent variables that affect the absent dependent variable. In the autocorrelation test, Watson's durbin value is between the acceptability limits in the absence of autocorrelation. So from the four tests, the model in this study passed the classic assumption test or the BLUE model.

\section{Regression Analysis}

The results of the calculation of the regression analysis of one with the DER dependent variable are presented in Table 2 . The results of the calculation of the two regression analysis with the dependent variable PBV are presented in Table 3.

The decision making criteria in the hypothesis test of regression equation 1 are with a confidence level $=95 \%$ or $\alpha=0.05$ and degrees of freedom $(\mathrm{df})=\mathrm{n}-\mathrm{k}-1$, or $135-2-1=132$, the value of $\mathrm{t}$ table $=1.9781$ is obtained. $\mathrm{H} 0$ is accepted if - $\mathrm{t}$ table $\leq \mathrm{t}$ count $\leq \mathrm{t}$ table or $\operatorname{sig} \alpha \geq 5 \%$ otherwise $\mathrm{H} 0$ is rejected if ( $\mathrm{t}$ count $<-\mathrm{t}$ table or $\mathrm{t}$ count $>\mathrm{t}$ table) and sig $\alpha<5 \%$.

Based on Table 2 the BRISK variable shows the value of $t-5.175<\mathrm{t}$ table -1.9781 with $\operatorname{sig} \alpha=0.000<0.05$ this means that the BRISK variable has a statistically significant effect on DER in the negative direction, so that $\mathrm{H} 1$ is accepted. Size variable shows the value of $t$ count $5.257>$ t table 1.9781 with sig $=0.000<0.05$ then the Size variable has a statistically significant positive effect on DER so that $\mathrm{H} 2$ is accepted.

Criteria for decision making in the hypothesis test of regression equation 2 are with a confidence level $=95 \%$ or $\alpha=0.05$ and degrees of freedom $(\mathrm{df})=\mathrm{n}-\mathrm{k}-1$ or $135-3-1=131$, then the value of $\mathrm{t}$ table $=1.97824$ is obtained. $\mathrm{H} 0$ is accepted if $-\mathrm{t}$ table $\leq \mathrm{t}$ count $\leq \mathrm{t}$ table or $\operatorname{sig} \alpha \geq$ $5 \%$ and $\mathrm{H} 0$ is rejected if ( $\mathrm{t}$ count $<-\mathrm{t}$ table or $\mathrm{t}$ count $>$ t table) and sig $\alpha<5 \%$.

Based on Table 3 the BRISK variable shows the value of $\mathrm{t}-4.870<\mathrm{t}$ table -1.97824 with $\operatorname{sig} \alpha=$ $0.000<0.05$ this means that the BRISK variable has a statistically significant effect on PBV in a negative direction, so that $\mathrm{H} 3$ is accepted. SIZE variable shows the value of $\mathrm{t}$ arithmetic 4.098 $>\mathrm{t}$ table 1.97824 with sig $\alpha=0.000<0.05$ then the Size variable has a statistically significant positive

Table 2. Regression Test Result 1

Coefficients $^{a}$

\begin{tabular}{lllllll}
\hline Model & \multicolumn{2}{l}{ Unstandardized Coefficients } & \multicolumn{2}{l}{ Standardized Coefficients } & \multirow{2}{*}{ T } & Sig. \\
\cline { 3 - 5 } & & B & Std. Error & Beta & & \\
\hline 1 & (Constant) & 0.102 & 1.366 & & 0.075 & 0.941 \\
& BRISK & -0.152 & 0.029 & -0.377 & -5.175 & 0.000 \\
& SIZE & 0.166 & 0.032 & 0.383 & 5.257 & 0.000 \\
\hline
\end{tabular}

a. Dependent Variable: DER

Sumber: Data sekunder diolah (2020)

Table 3. Regression Test Result 2

Coefficients $^{\mathrm{a}}$

\begin{tabular}{lllllll}
\hline Model & \multicolumn{2}{l}{ Unstandardized Coefficients } & \multicolumn{2}{l}{ Standardized Coefficients } & \multirow{2}{*}{ T } & \multirow{2}{*}{ Sig. } \\
\cline { 3 - 5 } & & $\mathrm{B}$ & Std. Error & Beta & & \\
\hline 1 & (Constant) & 0.805 & 3.023 & & 0.266 & 0.791 \\
& BRISK & -0.347 & 0.071 & -0.361 & -4.870 & 0.000 \\
& SIZE & 0.316 & 0.077 & 0.305 & 4.098 & 0.000 \\
& DER & 0.475 & 0.193 & 0.199 & 2.465 & 0.015 \\
\hline
\end{tabular}

a. Dependent Variable: PBV

Source: Data processed by (2020) 
effect on PBV so that H4 is accepted. DER variable shows the value of $t$ count $2.465>t$ table 1.97824 with sig $\alpha=0.015<0.05$, the DER variable is statistically significant positive effect on PBV so that $\mathrm{H} 5$ is accepted.

\section{Path Analysis}

To test $\mathrm{Ha} 6$ and $\mathrm{Ha} 7$ related to DER's ability to mediate the influence of BRISK and SIZE on PBV, a path analysis was performed. Based on table 2 and table 3 can be seen the coefficient of influence between variables. Figure 2 shows the path analysis model in this study. $\alpha=0.000<0.05$. This means that business risk has a statistically significant effect on DER in a negative direction. These results are consistent with $\mathrm{Ha} 1$, where business risk negatively influences the debt policy of property and real estate companies in the Indonesia Stock Exchange in 2014-2018.

The results of this study concur with research conducted by Mulianti (2010), Psillaki (2009) and Sari and Wirajaya (2017) which conclude that business risk has a negative effect on debt policy. But contrary to the results of research Wiagustini and Pertamawati (2015), Wimelda and Marlinah

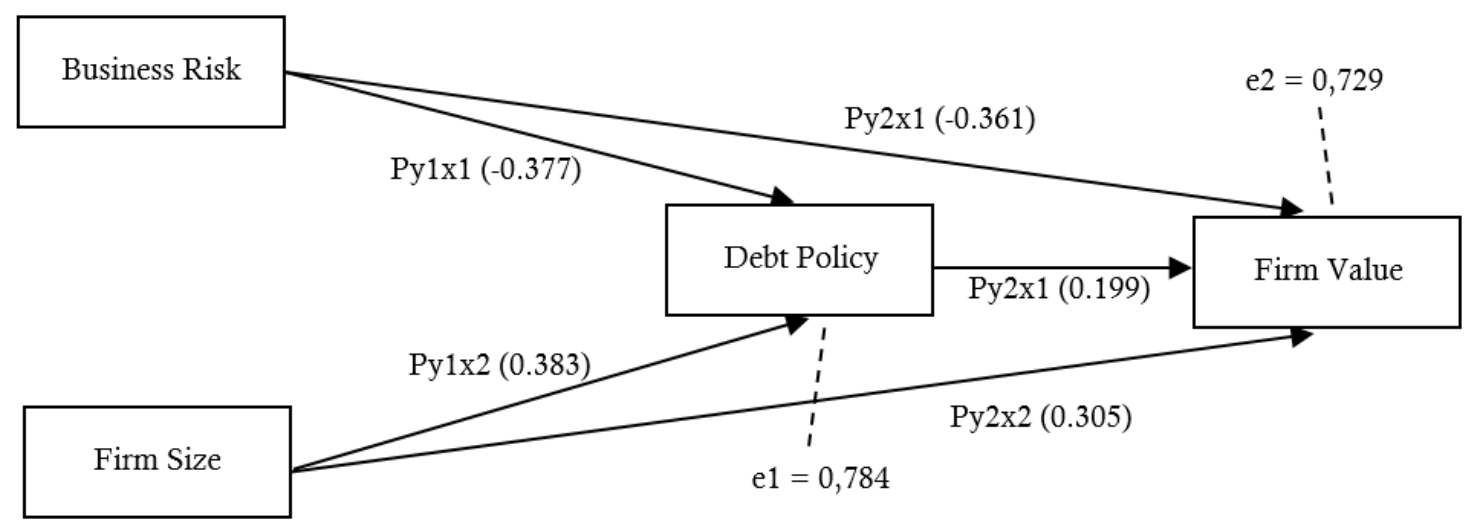

Figure 2. Path Analysis Model

Based on Figure 2 shows the direct effect of BRISK on PBV of -0.361 . The indirect effect of BRISK on PBV through DER is $-0.377 \times 0.199=$ -0.075 . So that the total indirect effect of BRISK on PBV through DER can be calculated at $-0,361$ $+(-0,075)=-0,436$. So it is known that the effect of the BRISK indirect path coefficient on PBV through DER $(-0.075)$ is greater than $(-0.361)$ the direct direct coefficient coefficient of BRISK on $\mathrm{PBV}$ so that $\mathrm{H} 6$ is accepted.

Based on Figure 2 the direct effect of SIZE on PBV is 0.305 . The indirect effect of SIZE on PBV through DER is $0.383 \times 0.199=0.076$. So it can be calculated the total indirect effect of SIZE on PBV through DER that is equal to $0.305+$ $0.076=0.381$. So it is known that the effect of the SIZE indirect path coefficient on PBV through DER (0.076) is smaller than (0.305) the coefficient of SIZE direct effect on PBV so that $\mathrm{H} 7$ is rejected.

\section{Effect of Business Risk on Debt Policy}

Based on the analysis results in this study it can be seen that business risk (BRISK) has a significant negative effect on debt policy. With a confidence level of $95 \%$ or $(\alpha)=0.05$, the value of $t$ arithmetic $(-5,175)<t$ table $(-1.9781)$ with sig
(2013) and Joni and Lina (2010) found that business risk has a positive effect on debt policy.

The results of this study support the trade off theory. The higher the business risk faced by the company, the lower the optimum debt ratio. This means that companies with high risk tend to have a low debt policy.

Business risk is one of the important indicators for companies in determining the company's funding system, especially in the decision to use debt. Companies that face high business risk as a result of their operations will avoid using high debt to fund their companies. Managers need to pay attention to business risks in making financing decisions with debt because the greater the risk of business with the use of large debt will make it difficult for companies to repay their debts, besides that companies with high levels of risk make creditors also have a reluctance to provide loans.

\section{Effect of Firm Size on Debt Policy}

Based on the results of the analysis in this study it can be seen that firm size significantly influences debt policy in a positive direction. With a confidence level of $95 \%$ or $(\alpha)=0.05$, firm size variable obtained $t$ value of $5.257>t$ table 1.9781 with sig $\alpha=0.000<0.05$ indicates that the variable size statistically has a significant positive effect on DER with positive direction. These re- 
sults are consistent with $\mathrm{Ha}$, where the firm size has a positive effect on the debt policy of property and real estate companies on the Indonesia Stock Exchange in 2014-2018.

The results of this study concur with research conducted by Wiagustini and Pertamawati (2015) and Alnajjar, (2015), and Salehi (2012) which concluded that firm size has a significant positive effect on debt policy. But contrary to the results of research by Khalid (2011) and Damayanti (2013) which shows the results that firm size has a negative influence on debt policy.

The results of this study support the signaling theory where the greater the firm size is a positive signal that shows the company has reached the stage of maturity, where at this stage the cash flow is positive, tends to have better conditions and is considered to have good prospects in a relatively long term, it also reflects that the company is more stable and more able to generate profits compared to companies with small total assets.

\section{Effect of Business Risk on Firm Value}

Based on the analysis results in this study it can be seen that business risk has a significant negative effect on firm value. With a confidence level of $95 \%$ or $(\alpha)=0.05$ business risk variables (BRISK) obtained the value of $t$ arithmetic $(-4,870)<\mathrm{t}$ table $(-1.97824)$ with sig $\alpha=0.000$ $<0.05$ this means that business risk is statistically significant effect towards firm value in a negative direction. This result is in accordance with $\mathrm{Ha} 3$, that business risk has a negative effect on the value of property and real estate companies in the Indonesia Stock Exchange in 2014-2018.

The results of this study are in line with research conducted by Wiagustini and Pertamawati (2015) and Sari and Wirajaya (2016) showing that business risk has a negative influence on firm value. But contrary to the results of research Saraswati et al. (2016) and Yuliani and Samadi (2013) which show that business risk has a positive influence on firm value. The results of this study support the signaling theory where the high risk of a company's business is a negative signal related to company conditions.

High business risk indicates high income variability. The higher business risk faced by the company, indicates the company is not in a stable condition because it is unable to maintain the level of profit so that it has the potential to fail to meet its obligations which then increases the risk of bankruptcy. Investors assess when bankruptcy occurs, most of the company's assets will be sold to pay off debt in large amounts compared to returning the value of the invested shares. This will be negatively assessed by investors, so the stock market price will go down, which will reduce the value of the company.

\section{Effect of Firm Size on Firm Value}

Based on the analysis of the results in this study it can be seen that the firm size significantly influences the firm value in a positive direction. With a confidence level of $95 \%$ or $(\alpha)=0.05$, the value of $\mathrm{t}$ arithmetic $4.098>\mathrm{t}$ table 1.97824 with sig $\alpha=0.000<0.05$ indicates that the firm size variable has a statistically significant positive effect on firm value. These results are in accordance with $\mathrm{Ha} 4$, that company size has a positive effect on the value of property and real estate companies in the Indonesia Stock Exchange in 2014-2018.

The results of this study concur with the research conducted by Angga and Wiksuana (2016), Wiagustini and Pertamawati (2015) and Rasyid et al. (2015) which concluded that firm size had a significant positive effect on firm value. But contrary to the results of the research of Rai and Merta (2016) which illustrates that firm size has a negative influence on firm value. The results of this study support signaling theory, where a large firm size shows more stable conditions, especially in the return of stock returns to investors higher. This will be responded positively by investors and makes the company's stock price increase so that it will increase the firm value.

The greater firm size shows the company has reached the stage of maturity, where at this stage cash flow is positive, tends to have better conditions, and is considered to have good prospects in a relatively long period of time. The larger the size of the company, investors assume the company will provide higher prosperity compared to smaller companies so that the stock price rises and increases firm value.

\section{Effect of Debt Policy on Firm Value}

Based on the analysis of the results in this study it can be seen that the debt policy has a significant positive effect on firm value. With a confidence level of $95 \%$ or $(\alpha)=0.05$, the value of $\mathrm{t}$ arithmetic $2,465>\mathrm{t}$ table 1.97824 with sig $\alpha=$ $0.015<0.05$ shows that debt policy has a statistically significant positive effect on firm value. These results are consistent with the fifth alternative hypothesis (Ha5), that debt policy has a positive effect on the firm value of property and real estate companies on the Indonesia Stock Exchange in 2014-2018.

The results of this study concur with research conducted by Sari and Wirajaya (2017), Angga and Wiksuana (2016), Rai and Mertha 
(2016), and Saraswati et al. (2016) which concluded that debt policy has a significant positive effect on firm value. But contrary to the results of research Hartono et al. (2013), Mahendra et al. (2012), Ogolmagai (2013), and Kodongo et al. (2014) which obtained the result that debt policy has a negative and significant effect on firm value.

The results of this study support the signaling theory in which the greater the debt policy adopted by the company, is considered a positive signal by investors and creditors related to the company's confidence in its future business prospects so as to increase the firm value. Increased debt is interpreted by outsiders as the company's ability to pay obligations in the future and this will be a signal that will be responded positively by the market. The more debt, the company has many opportunities to use their capital for expansion or development in the hope that the company will grow, so the profits for investors will also increase so that investors are interested in buying the company's shares, this at the same time increasing the value of the company.

The results of this study also support modigliani miller theory, which states that the use of debt will increase the value of the company because the cost of debt interest is a cost that reduces tax payments. The statement is also in accordance with the statement of Brigham and Houston (2010) which explains that the use of a larger debt can increase the value of the company because the use of debt can save on taxes paid because debt raises interest payments which reduce the amount of income subject to tax so that the value of the company increases.

\section{Effect of Business Risk on Firm Value through the Debt Policy}

Based on the results of the study showed that the sixth alternative hypothesis (H6) which states that business risk affects the firm value through debt policy is accepted. This indicates that the higher the business risk in the company will reduce the company's debt policy which will then reduce the firm value.

The results showed that the effect of the indirect path coefficient of BRISK on PBV through DER was greater than the coefficient of direct influence of BRISK on PBV of $-0.075>-0.361$ so that debt policy was able to mediate the effect of business risk on firm value. The results of this study are in line with Wiagustini and Pertamawati (2015) which states that business risk influences company value through debt policy.

Business risk can increase when companies use high debt to meet their funding needs.
Risks arise along with the emergence of the burden of costs on loans made by the company. Business risk can increase when companies use high debt to meet their funding needs. Risks arise along with the emergence of the burden of costs on loans made by the company. Business risk can increase when companies use high debt to meet their funding needs. Risks arise along with the emergence of the burden of costs on loans made by the company. The greater the burden of costs to be borne, the greater the risk faced by the company. Investors will assume that when a company faces an increasing risk of bankruptcy due to the high burden of debt costs, the company will sell its assets to pay off debt, not to return the value of shares invested by investors and creditors. As a result, investors and creditors will not be interested in investing their capital in the companies concerned so that the stock market prices will go down, which in turn will reduce the company's value. Based on this, companies with high business risks result in the funding decisions they choose causing the company's value to fall in the eyes of investors.

\section{Effect of Firm Size on Firm Value through the Debt Policy}

Based on the results of the study showed that the seventh alternative hypothesis ( $\mathrm{Ha} 7)$ which states the size of the company affects the value of the company through debt policy as an intervening variable, is rejected. This indicates that the debt policy is not able to mediate the relationship between firm size and firm value.

The results showed that the effect of the SIZE indirect path coefficient on PBV through DER was smaller than the coefficient of SIZE direct influence on PBV $0.076<0.305$ so that debt policy cannot mediate the effect of firm size on firm value. The results of the study are in line with Wiagustini and Pertamawati (2015) which states that debt policy is not able to interfere with the influence of firm size on firm value.

The inability of debt policy to mediate the effect of company size on the value of the company is caused by the size of the company does not make the company do debt for the development of its products and services. The greater the size of the company shows the company has reached the stage of maturity, where at this stage the cash flow is positive, tends to have better conditions, and is considered to have good prospects in a relatively long period of time, while also reflecting that the company is more stable and more able to generate profits compared to companies with small total assets. So companies do not need debt 
to meet their funding needs. The conditions are getting better, and are considered to have good prospects in a relatively long period of time, while also reflecting that the company is more stable and more able to generate profits compared to companies with small total assets. So the company does not need debt to meet its funding needs.

\section{CONCLUSION AND RECOMMENDATION}

The conclusion from the results of this stu$\mathrm{dy}$ is that business risk has a negative effect on debt policy, while firm size has a positive effect on debt policy. Business risk has a negative effect on firm value while firm size and debt policy has a positive effect on firm value. By using a path test, the debt policy is only able to mediate the effect of business risk on the firm value of property and real estate companies listed on the Indonesia Stock Exchange in 2014-2018.

This research is limited to property and real estate sector companies listed on the Indonesia Stock Exchange in 2014-2018, so the conclusions cannot be generalized to companies in other sectors. The researcher suggests that there are similar studies with different variables, for example by adding financial and non-financial variables such as free cash flow, investment opportunities, shareholding structures, etc. and in different situations, namely more recent observation periods and other research objects, and may be able to carried out research for other industries or sectors as a whole.

Suggestions for companies to be more careful in making decisions that can affect changes in business risk, firm size, and debt policy, as well as other variables that will also affect the firm value.

If investors want to make an investment, they can consider the variables of business risk, company size and the existing debt policy in the company, because based on the results of this study, these three variables have proven to have a significant effect on firm value.

\section{REFERENCES}

Agustina, C. \& Ardiansari, A. (2015). Pengaruh Faktor Ekonomi Makro dan Kinerja Keuangan terhadap Nilai Perusahaan. Management Analysis Journal, 4(1).

Alkhatib, K., Al-Sraheen, D. \& Marji, O. (2017). Determinants of Capital Structure Decisions: An Empirical Study from Developing Country. International Business Management, 11 (1).

Alnajjar, M. I. M. (2015). Business Risk Impact on Capital Structure: A Case of Jordan Industrial Sector. Global Journal of Management and Business Reasearch, 15(1).
Anggraeni, H. S., Fitriany, F., \& Fatima, E. (2017). Analisis Pengaruh Struktur Modal dan Struktur Kepemilikan terhadap Nilai Perusahaan. Simposium Akuntansi Nasional 18.

Atmaja, L. S. (2008). Manajemen Keuangan. Yogyakarta: CV. ANDI OFFSET

Brigham \& Houston. (2006). Dasar-dasar Manajemen Keuangan, Buku 2, Edisi Kesepuluh. Jakarta: Penerbit Salemba Empat.

Brigham \& Houston. (2010). Dasar-dasar Manajemen Keuangan Buku 1 Edisi kesebelas. Jakarta: Salemba Empat.

Cahyaningdyah, D., \& Ressany, Y. D. (2011). Pengaruh Kebijakan Manajemen Keuangan terhadap Nilai Perusahaan. Jurnal Dinamikan Manajemen, 3(1), 20-28.

Cheng, M. C., \& Zuwei, C. T. (2011). The Effect of Leverage on Firm Value and How The Firm Financial Quality Influence on This Effect. World Journal of Management, 3(2), 30-53.

Damayanti. (2013). Pengaruh Struktur Aktiva, Ukuran Perusahaan, Peluang Bertumbuh dan Profitabilitas terhadap Struktur Modal. Jurnal Perspektif Bisnis, 1(1), 17-32.

Erfiana, D., \& Ardiansari, A. (2016). Pengaruh Masalah Keagenan, Kebijakan Dividen, dan Variabel Moderasi Growth Opportunity terhadap Nilai Perusahaan. Management Analysis Journal, $5(3)$.

Harjanti, T. T., \& Tandelili, E. (2007). Pengaruh Firm Size, Tangible Asset, Growth Opportunity, Profitability dan Business Risk pada Struktur Modal Perusahaan Manufaktur: Studi Kasus di BEJ. Jurnal Bisnis dan Ekonomi, 1(1), 1-10.

Hartono, U., Subroto, B., Djumahir, and Irianto, G. (2013). Firm Characteristics, Corporate Governance and Firm Value. International Journal of Business and Behavioral Sciences, 3(8), 9-18.

Haryanto, S. (2014). Identifikasi Ekspektasi Investor melalui Kebijakan Struktur Modal, Profitabilitas, Ukuran Perusahaan dan GCPI. Jurnal Dinamikan Manajemen, 5(2), 20-28.

Hermuningsih, S. (2012). Pengaruh Profitabilitas, Size terhadap Nilai Perusahaan dengan Sruktur Modal sebagai Variabel Intervening. Jurnal siasat bisni, 18(2), 232-242.

Jannah, I. R., \& Khoiruddin, M. (2017). Peran Financial Distress Memediasi Kepemilikan Institusional, Kepemilikan Manajerial terhadap Return Saham. Management Analysis Journal, 6(3).

John \& Gill, A. (2012). The Impact of Corporate Goverance and Financial Leverage on the Value of American Firms. International Research Journal of Finance and Economics, 1-14.

Joni \& Lina. (2010). Faktor-Faktor yang Mempengaruhi Struktur Modal. Jurnal Bisnis dan Akuntansi STIE Trisakti, 12(2), 81-96.

Khalid, S. (2011). Financial Reforms and Dynamics of Capital Structure Choice: a Case of Publically Listed Firms of Pakistan. Journal of Management Research, 3(1), 1-16.

Kodongo, O., Mokoaleli-Mokoteli, T., \& Maina, L. 
N. (2015). Capital Structure, Profitability and Firm Value: Panel Evidence of Listed Firms in Kenya. African Finance Journal, 17(1), 1-20.

Maftukhah, I. (2013). Kepemilikan Manajerial, Kepemilikan Institusional, dan Kinerja Keuangan sebagai Penentu Struktur Modal Perusahaan. Jurnal Dinamika Manajemen, 4(4), 69-81.

Mulianti, F. M. (2010). Analisis Faktor-Faktor yang Mempengaruhi Kebijakan Hutang dan Pengaruhnya terhadap Nilai Perusahaan. Tesis. Semarang: Pascasarjana Universitas Diponegoro.

Pratama, I. G. B. A., \& Wiksuana, I. G. B. (2016). Pengaruh Ukuran Perusahaan dan Leverage terhadap Nilai Perusahaan dengan Profitabilitas sebagai Variabel Mediasi. E-Jurnal Manajemen Unud, 5(2),1338-1367.

Putri, G. A. P. (2012). Analisis Pengaruh Kepemilikan Institusional Free Cast Flow Investment Opportunity Set terhadap Nilai Perusahaan dengan Kebijakan Hutang sebagai Variabel Interveniang. Skripsi. Semarang: Universitas Diponegoro.

Rai, N. K. P. \& Sudiartha, I. G. M. (2016). Pengaruh Struktur Modal, Kebijakan Dividen, dan Ukuran Perusahaan terhadap Nilai Perusahaan pada Perusahaan Manufaktur. E-Jurnal Manajemen Unud, 5(3), 1572-1598.

Rastogi, S., \& Saxena, P. (2016). Leverage and Firm Value: An Empirical Review of Concept with Reference to High Leveraged Indian Companies. International jurnal of reasearch in IT and Management, 6, 99-104.

Ridloah, S. (2010). Faktor Penentu Struktur Modal: Studi Empirik pada Perusahaan Multifinansial. Jurnal Dinamika Manajemen, 1(2), 144-153.
Sari, E. L., \& Wijayanto, A. (2015). Pengaruh Keputusan Investasi, Pendanaan, dan Dividen terhadap Nilai Perusahaan dengan Risiko sebagai Variabel Mediasi. Management Analysis Journal, 4(4).

Sari, L. A., \& Yanthi, H. (2009). Debt to Equity Ratio, Degree of Operating Leverage, Stock Beta, and Stock Returns of Food \& Beverages on IDX. Journal of Applied Finance and Accounting (JAFA), 2(1).

Sari, P. S. P., \& Wirajaya, I. G. A. (2017). Pengaruh Free Cash Flow dan Risiko Bisnis pada Nilai Perusahaan dengan Kebijakan Hutang sebagai Variabel Intervening. E-Jurnal Akuntansi Universitas Udayana, 18, 2260-2289.

Jia, W., \& Chen, B. (2008). Financial Risk, Business Risk and Firm Value for Logistics Industry. Proceedings of the 4th International Conference on Wireless Communications, Networking and Mobile Computing, 1-4.

Wiagustini, N. L. P., \& Pertamawati, N. P. (2015). Pengaruh Risiko Bisnis dan Ukuran Perusahaan pada Struktur Modal dan Nilai Perusahaan pada Perusahaan Farmasi di Bursa Efek Indonesia. Jurnal Manajemen, Strategi Bisnis dan Kewirausahaan, 9(2).

Wimelda, L., \& Marlinah, A. (2013). Variabel-Variabel yang Mempengaruhi Struktur Modal pada Perusahaan Publik Sektor Non Keuangan. Jurnal Media Bisnis STIE Trisakti, 3(1), 200-213.

Yuliani, I., \& Samadi, W. B. (2013). Keputusan Investasi, Pendanaan, dan Dividen terhadap Nilai Perusahaan dengan Risiko Bisnis sebagai Variabel Mediasi. Jurnal Keuangan dan Perbankan Universitas Sriwijaya, 17(3), 362-375. 